\title{
ANALISIS EFISIENSI DAN KEUNTUNGAN USAHATANI JAGUNG DI DESA WARINTA KECAMATAN PASARWAJO KABUPATEN BUTON
}

\author{
Muzuna \\ Program Studi Agribisnis, Fakultas Pertanian \\ Universitas Muhammadiyah Buton \\ Jl. Betoambari No. 36 Baubau \\ e-mail: muzunaumb@gmail.com
}

\begin{abstract}
The research objectives are as follows: (1) To determine the level of efficiency in the use of seed, fertilizer and labor production factors in corn farming in Warinta Village, Pasarwajo Sub-district, Buton Regency; and (2) To find out the great benefits of corn farming in Warinta Village, Pasarwajo Sub-district, Buton Regency. The population in this study were all farmers engaged in maize in Warinta Village, Pasarwajo Sub-district, Buton Regency, amounting to 32 people because the population was less than 100 and the sample was taken by census. To estimate the production function of maize farming, the frontier production function equation model is used as follows: $\operatorname{Ln} Y=\beta 0+\beta 1 \ln X 1+\beta 2 \ln X 2+\beta 3 \ln X 3+e$ and to calculate the price efficiency, the production function used is: $N P M X=P X$ or $N P M X / P X=1$. The conclusions of the results of the study are: (1) Large factor prices efficiency of labor production amounted to 0.8670 . There needs to be a reduction in labor outpouring factors so that efficient use of labor can be achieved; (2) The efficiency of the price of fertilizer production factor is 11.1422. It is necessary to add fertilizer production factors so that the efficiency of fertilizer use can be achieved; (3) The amount of efficiency in the price of seed production factors is 3.9604. Need for additional seed production factors so that efficient use of seedlings is achieved; and (4) The average income of a one-time hybrid corn farmer in Warinta Village, Pasarwajo District, Buton Regency is IDR 5,923,543.88 with an average total revenue of IDR 7,361,046.88 and the total cost incurred in the amount of IDR 1,437 .502 .99 .
\end{abstract}

Keywords: corn farming, price efficiency

\begin{abstract}
Abstrak
Adapun tujuan penelitian adalah sebagai berikut: (1) Untuk mengetahui besar tingkat tingkat efisiensi penggunaan faktor produksi bibit, pupuk, dan tenaga kerja pada usahatani jagung di Desa Warinta Kecamatan Pasarwajo Kabupaten Buton; dan (2) Untuk mengetahui besar keuntungan usahatani jagung di Desa Warinta Kecamatan Pasarwajo Kabupaten Buton. Populasi pada penelitian ini adalah seluruh petani yang berusahatani jagung di Desa Warinta Kecamatan Pasarwajo Kabupaten Buton yang berjumlah 32 orang, karena populasi kurang dari 100 maka penarikan sampel dilakukan secara sensus dengan mengambil keseluruhan dari populasi sebagai sampel yaitu 32 orang. Untuk menduga fungsi produksi usahatani jagung digunakan model persamaan fungsi produksi frontier sebagai berikut: $\operatorname{Ln} Y=\beta 0+\beta 1 \ln X 1+$ $\beta 2 \ln X 2+\beta 3 \ln X 3+$ e dan untuk menghitung efisiensi harga maka fungsi produksi yang
\end{abstract}


digunakan adalah: NPMX $=$ PX atau NPMX /PX $=1$. Kesimpulan hasil penelitian adalah: (1) Besar efisiensi harga faktor produksi tenaga kerja adalah sebesar 0,8670. Perlu adanya pengurangan faktor curahan tenaga kerja agar efisiensi penggunaan tenaga kerja dapat tercapai; (2) Besar efisiensi harga faktor produksi pupuk adalah sebesar 11,1422. Perlu adanya penambahan faktor produksi pupuk agar efisiensi penggunaan pupuk dapat tercapai; (3) Besarnya efisiensi harga faktor produksi bibit adalah sebesar 3,9604. Perlu adanya penambahan faktor produksi bibit agar efisiensi penggunaan bibit tercapat; dan (4) Pendapatan rata-rata petani jagung hibrida satu kali panen di Desa Warinta Kecamatan Pasarwajo Kabupaten Buton adalah sebesar Rp 5.923.543,88 dengan jumlah penerimaan ratarata sebesar Rp 7.361.046,88 dan jumlah biaya yang dikeluarkan sebesar Rp 1.437.502,99.

Kata kunci: usahatani jagung, efisiensi harga

\section{PENDAHULUAN}

\section{Latar Belakang}

Jagung merupakan komoditas tanaman pangan yang memiliki peranan penting dan strategis setelah padi dalam pembangunan nasional. Posisi strategis Indonesia yang beriklim tropis dan memiliki tanah yang subur dan laut yang luas, membuat Indonesia dapat digolongkan sebagai negara agraris maritim serta selayaknya menempatkan produk pertanian dan kelautan sebagai kekuatan utama, salah satu produk pertanian yang seharusnya bisa dikembangkan adalah jagung (Kemendag, 2012).

Jagung merupakan salah satu tanaman serealia yang menduduki posisi terpenting kedua setelah padi karena memiliki banyak manfaat ekonomi, hampir semua bagian tanamannya dapat dimanfaatkan, baik untuk konsumsi rumah tangga, ternak maupun untuk keperluan industri pakan dan industri pengolahan berbagai jenis produk olahan. Secara umum jagung yang beredar di pasaran hanya warna putih dan kuning, warna putih biasanya dimanfaatkan untuk pangan, sedangkan yang kuning dimanfaatkan untuk keperluan industri pakan, dan juga digunakan untuk keperluan industri pengolahan makanan ringan, seperti keripik, kerupuk dan marning jagung.

Upaya swasembada jagung akan terus digulirkan, mengingat saat ini, jagung merupakan bahan makanan penghasil karbohidrat kedua setelah padi. Selain dikonsumsi lansung, jagung digunakan sebagai pakan ternak penghasil susu,daging dan juga sebagai bahan baku industri. Oleh karena itu, jagung merupakan komoditas mempunyai nilai strategis seperti halnya beras.

Untuk mewujudkan pertanian berkelanjutan petani perlu memanfaatkan faktor produksi secara efektif dan efisien untuk produksi usahataninya. Efisiensi produksi hendaknya penting diperhatikan oleh petani. Upaya-upaya peningkatan produksi tanaman pangan melalui jalur ekstensifikasi tampaknya semakin sulit, terbatasnya lahan pertanian produktif dan alih fungsi lahan dari pertanian ke non pertanian yang sulit dibendung karena berbagai alasan. Upaya peningkatan produksi tanaman pangan melalui efisiensi produksi menjadi salah satu pilihan yang tepat. Dengan efisiensi, petani dapat menggunakan input produksi sesuai dengan ketentuan untuk mendapat produksi yang optimal.

Kecamatan Pasarwajo merupakan salah satu kecamatan di Kabup berpotensi untuk pengembangan komoditi jagung karena memiliki permi l yang r lokal

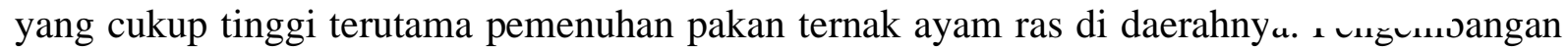
jagung dilaksanakan berbasis agribisnis yaitu penyediaan sarana produksi seperti bibit, pupuk dan perbaikan budidaya serta peningkatan kelembagaan kelompok tani. Berikut data luas 
tanam, luas panen, produktivitas dan produksi jagung di Kecamatan Pasarwajo Kabupaten Buton kurun waktu tiga tahun terakhir.

Tabel 1. Luas tanam, luas panen, produktivitas dan produksi jagung di Kecamatan Pasarwajo Tahun $2014-2018$

\begin{tabular}{cccc}
\hline Tahun & Luas Panen (Ha) & $\begin{array}{c}\text { Produktivitas } \\
\text { (Kw/Ha) }\end{array}$ & $\begin{array}{c}\text { Produksi } \\
\text { (Ton) }\end{array}$ \\
\hline 2014 & 176 & 91,39 & $1.608,46$ \\
\hline 2015 & 176 & 91,39 & $1.608,46$ \\
\hline
\end{tabular}

Sumber Data: Pasarwajo dalam angka tahun 2015 dan 2018

Berdasarkan Tabel 1 diatas menunjukkan bahwa pada Tahun 2014 produksi jagung di Desa Warinta Kecamatan Pasarwajo mencapai 1.608,46 Ton dengan luas panen 176 Ha dan produktivitas mencapai $91,39 \mathrm{Kw} / \mathrm{Ha}$. Hal ini tetap berlangsung hingga tahun 2015, tidak terjadi perubahan jumlah produksi, luas panen dan produktivitas jagung di Desa Warinta Kecamatan Pasarwajo.

Untuk meningkatkan produktivitas jagung, seharusnya petani perlu memperhatikan faktor-faktor produksi, agar dapat digunakan secara efisien sehingga petani dapat memperoleh keuntungan usahatani sebesar-besarnya dan akhirnya dapat menambah pendapatan serta meningkatkan kesejahteraan petani. Berdasarkan latar belakang inilah yang mendorong penulis mengangkat judul "Analisis Efisiensi dan Keuntungan Usahatani Jagung (Studi di Desa Warinta Kecamatan Pasarwajo Kabupaten Buton”.

\section{Tujuan Penelitian}

Adapun tujuan penelitian adalah sebagai berikut:

1. Untuk mengetahui besar tingkat tingkat efisiensi penggunaan faktor produksi bibit, pupuk, dan tenaga kerja pada usahatani jagung di Desa Warinta Kecamatan Pasarwajo Kabupaten Buton.

2. Untuk mengetahui besar keuntungan usahatani jagung di Desa Warinta Kecamatan Pasarwajo Kabupaten Buton.

Penelitian ini diharapkan dapat bermanfaat sebagai berikut:

Penelitian ini diharapkan dapat bermanfaat sebagai berikut:

1. Sebagai bahan informasi bagi petani tentang pengaruh penggunaan faktor-faktor produksi tenaga kerja, bibit, dan pupuk terhadap produksi jagung di Desa Warinta Kecamatan Pasarwajo Kabupaten Buton;

2. Bahan informasi dan studi bagi pihak-pihak yang terkait terhadap pengembangan usahatani jagung.

\section{Waktu dan Lokasi Penelitian}

\section{METODE PENELITIAN}

Penelitian ini dilaksanakan pada bulan Juli sampai dengan Agustus 2018 di Desa Warinta Kecamatan Pasarwajo Kabupaten Buton dengan pertimbangan bahwa daerah tersebut merupakan sentral produksi jagung untuk Kabupaten Buton.

\section{Populasi dan Sampel}

Populasi pada penelitian ini adalah seluruh petani yang berusahatani jagung di Desa Warinta Kecamatan Pasarwajo Kabupaten Buton yang berjumlah 32 orang, karena populasi kurang dari 100 maka penarikan sampel dilakukan secara sensus dengan mengambil 
keseluruhan dari populasi sebagai sampel yaitu 32 orang. Hal ini sesuai dengan pendapat Suharsini Arikunto (1993) bahwa apabila subyeknya kurang dari 100, lebih baik diambil semua sehingga pengambilan sampel dilakukan secara sensus. Selanjutnya jika jumlah subyeknya diatas 100 maka dapat diambil antara $10-15 \%$ atau $20-25 \%$ atau lebih.

\section{Jenis dan Sumber Data}

Jenis dan sumber data menggunakan data primer dan data sekunder. Data primer adalah data yang langsung dan segera diperoleh dari sumber data oleh peneliti. Data primer dalam penelitian ini diperoleh langsung dari petani responden melalui wawancara langsung dengan menggunakan kuesioner yang telah disiapkan. Data sekunder diperoleh dari Badan Pusat Statistik (BPS) Kabupaten Buton, Dinas Pertanian Kabupaten Buton, dan Kantor Kecamatan Pasarwajo.

\section{Teknik Pengumpulan Data}

Teknik pengumpulan data dengan wawancara, observasi dan pencatatan. Teknik wawancara digunakan untuk mengumpulkan data primer melalui wawancara langsung kepada responden berdasarkan daftar pertanyaan (kuesioner) yang telah disiapkan sebelumnya. Teknik observasi dilakukan dengan

mengadakan pengamatan langsung terhadap objek yang akan diteliti sehingga didapatkan gambaran yang jelas mengenai objek yang akan diteliti. Sedangkan teknik pencatatan digunakan untuk mengumpulkan data sekunder yaitu dengan mencatat data yang ada pada instansi pemerintah atau lembaga yang terkait dengan penelitian ini.

\section{Variabel Penelitian}

Variabel yang diamati pada penelitian ini yaitu:

1. Identitas responden: umur, pendidikan, pengalaman berusahatani dan jumlah tanggungan keluarga

2. Identitas usahatani: luas lahan garapan, jumlah produksi, biaya produksi dan harga jual.

3. Faktor produksi: tenaga kerja, pupuk, dan bibit

\section{Teknik Analisis Data}

Data yang telah dikumpulkan di lapangan diolah dengan mentabulasikan dan seterusnya dipindahkan kedalam bentuk tabularis sesuai dengan kebutuhan analisis.

\section{a. Analisis Efisiensi}

Untuk menduga fungsi produksi usahatani jagung digunakan model persamaan fungsi produksi frontier sebagai berikut:

$$
\operatorname{Ln} Y=\beta_{0}+\beta_{1} \ln X_{1}+\beta_{2} \ln X_{2}+\beta_{3} \ln X_{3}+e
$$

Dimana:

$\mathrm{Y}=$ produksi Jagung ipilan kering $(\mathrm{kg})$

$\mathrm{X}_{1}=$ jumlah tenaga kerja yang digunakan $(\mathrm{HOK})$

$\mathrm{X}_{2}=$ jumlah pupuk urea yang digunakan $(\mathrm{kg})$

$\mathrm{X}_{3}=$ jumlah bibit yang digunakan $(\mathrm{kg})$

Berdasarkan persamaan fungsi produksi frontier diatas dianalisis tingkat efisiensi harga. Efisiensi harga atau efisiensi alokatif adalah apabila nilai dari produk marginal sama dengan harga produksi yang bersangkutan Efisiensi merupakan upaya penggunaan input sekecil- 
kecilnya untuk mencapai apabila perbandingan antara nilai input tersebut (Px). (Nicholson 1995). Untuk menghitung efisiensi harga maka fungsi produksi yang digunakan adalah:

NPMX $=$ PX atau NPMX $/ P X=1$

b. Y.Py / $\mathrm{X}=\mathrm{PX}$ atau b.Y.Py / X.PX $=1$

$\mathrm{b}$ adalah koefisien regresi yang sekaligus menggambarkan elastisitas prduksi sehingga dapt ditulis sebagai berikut:

$\mathrm{NPM}=\mathrm{bYPy} / \mathrm{X}=\mathrm{PX}$

Dimana:

$\mathrm{b}=$ elastisitas produksi

$\mathrm{Y}=$ produksi

Py = harga produksi

$\mathrm{X}=$ jumlah faktor produksi $\mathrm{X}$

$\mathrm{PX}=$ harga faktor produksi

Menurut Soekartawi (2003), dalam kenyataan yang sebenarnya persamaan diatas nilainya tidak sama dengan 1, yang seringkali terjadi adalah:

a. $(\mathrm{NPM} / \mathrm{Px})>1$, hal ini berarti bahwa penggunaan faktor produksi X belum efisien. Agar bisa mencapai efisien, maka penggunaan faktor produksi X perlu ditambah.

b. (NPM / Px $)<1$, hal ini berarti bahwa penggunaan faktor produksi X tidak efisien, sehingga perlu dilakukan pengurangan faktor produksi $\mathrm{X}$ agar dapat tercapai efisien.

\section{b. Keuntungan (Profit)}

Menurut Tohir (1982) secara matematis keuntungan (profit) dapat di tulis sebagai berikut:

$\pi=\mathbf{T R}-\mathbf{T C}$

TR $=$ Y. Hy

Keterangan:

$\boldsymbol{\pi}$ : Pendapatan (Rp);

TR: Total Revenue/Total Penerimaan (Rp);

TC : Total Cost / Biaya Total (Rp);

Hy: Harga jual (Rp).

$\mathrm{Y}$ : Total produksi $(\mathrm{Kg} / \mathrm{Ha})$

\section{HASIL DAN PEMBAHASAN}

\section{Karakteristik Petani Responden}

Karakteristik petani responden merupakan salah satu variabel yang memberikan pengaruh dan kontribusi dalam kegiatan usahatani jagung hibrida. Adapun karakteristik petani responden dalam penelitian ini meliputi umur, tingkat pendidikan, pengalaman berusahatani, jumlah tanggungan dan luas lahan. Karakteritik 32 petani responden dapat dijelaskan sebagai berikut

1. Umur Petani

Umur menggambarkan kondisi seseorang dalam melakukan aktivitas kegiatan usahatani. Umur muda akan lebih dinamis dan selalu mengikuti perkembangan zaman sehingga pada petani yang berumur muda ditemukan adanya petani - petani yang progresif yang selalu mau mencoba metode- metode baru dan cara - cara baru. Sebaliknya umur yang tua akan lebih berhati - hati dalam segala hal terkait dengan penerapan metode maupun cara - 
cara baru. Umur petani responden. Rata - rata umur petani responden 46,8 tahun dengan kisaran umur 23 tahun - 67 tahun. Untuk lebih jelas keadaan umur petani responden dapat dilihat pada Tabel 2 .

Tabel 2. Keadaan Umur Petani Responden di Desa Warinta Tahun 2018

\begin{tabular}{|c|c|c|c|}
\hline No. & $\begin{array}{c}\text { Golongan Umur } \\
\text { (tahun) }\end{array}$ & $\begin{array}{c}\text { Jumlah } \\
\text { (orang) }\end{array}$ & $\begin{array}{c}\text { Persen } \\
(\boldsymbol{\%})\end{array}$ \\
\hline 1 & $23-54$ & 27 & 84,38 \\
\hline 2 & $55-71$ & 5 & 15,62 \\
\hline & Jumlah & 32 & 100,00 \\
\hline
\end{tabular}

Tabel 2 menunjukan bahwa petani responden yang berada pada kelompok produktif berjumlah 27 orang atau $84,38 \%$, sedangkan petani responden yang berada pada kelompok umur kurang produktif berjumlah 5 orang atau 15,62\%. Keadaan ini menggambarkan bahwa mayoritas petani responden berada dalam kelompok umur produktif. Pada usia kelompok umur produktif, petani responden dapat bekerja lebih keras, dan kreatif dan lebih mudah menerima informasi dan mengadopsi teknologi baru sehingga diharapkan dengan umur produktif tersebut petani responden dapat menghasilkan produksi yang maksimal.

\section{Tingkat Pendidikan}

Tingkat pendidikan yang telah dicapai akan menggambarkan keadaan cara dan arah berpikir petani responden dalam mengelola dan meresponden segala hal yang berkaitan dengan kegiatan pengembangan usahataninya. Untuk lebih jelasnya keadaan tingkat pendidikan petani responden dapat dilihat pada Tabel 3 sebagai berikut

Tabel 3. Keadaan Pendidikan Petani Responden di Desa Warinta Tahun 2017

\begin{tabular}{clcc}
\hline No. & \multicolumn{1}{c}{ Tingkat Pendidikan } & Jumlah (Orang) & Persen (\%) \\
\hline 1 & Tidak tamat SD & 14 & 43,75 \\
\hline 2 & SD & 7 & 21,88 \\
\hline 3 & SLTP & 6 & 18,75 \\
\hline 4 & SLTA & 5 & 15,62 \\
\hline & Total & 32 & 100,00 \\
\hline
\end{tabular}

Tabel 3 menunjukan petani responden yang tidak sekolah berjumlah 14 orang atau $43,75 \%$, petani responden yang tamat Sekolah Dasar berjumlah 7 orang atau $21,88 \%$. Petani responden yang tamat Sekolah Menengah Pertama berjumlah 6 orang atau 18,75\%, petani responden yang tamat Sekolah Menengah Atas berjumlah 5 orang atau 15,62\%. Semakin tinggi pendidikan petani responden maka semakin baik cara berpikir dalam mengembangkan usahataninya. Tingkat pendidikan petani responden hanya 5 orang atau $15,62 \%$ yang tamat Sekolah Menengah Atas.

Keadaan ini menggambarkan bahwa kesadaram masyarakat Desa Warinta masih rendah. Hal ini dapat dijelaskan masih ada sebagian petani responden yang tidak tamat SD dan hanya 15,62\% yang tamat Sekolah Menengah Atas. Kondisi ini tentu menggambarkan sumber daya petani responden kurang berkualitas. Olehnya itu perlu ada upaya - upaya yang dilakukan oleh pemerintah setempat dan dukungan dari petani responden untuk mengikuti kegiatan penyuluhan maupun pelatihan sebagai upaya peningkatan sumber daya manusia 
dalam hal tingkat pemahaman penggunaan teknologi baru yang sangat besar pengaruhnya terhadap keberhasilan petani dalam melakukan kegiatan usahatani jagung hibrida.

\section{Jumlah Tanggungan Keluarga}

Jumlah tanggungan keluarga akan menggambarkan 2 hal dari kehidupan petani sebagai kepala keluarga. Yang pertama adalah jumlah tanggungan yang dimiliki tersebut akan menggambarkan besarnya jumlah tenaga kerja yang akan memberikan curahan tenaga kerja pada saat akan melakukan kegiatan usahatani dan yang kedua adalah akan menggmabrkan besarnya jumlah biaya yang akan dikeluarkan terutama biaya konsumsi dan kebutuhan lainnya. Jumlah tanggungan kelaurga petani responden rata -rata berjumlah 4,6 atau 5 orang dengan kisaran jumlah tanggungan keluarga berjmlah 2 orang -8 orang. Untuk lebih jelas keadaan jumlah tanggungan keluarga petani responden dapat dilihat pada Tabel 4.

Tabel 4. Keadaan Jumlah Tanggungan Keluarga Petani di Desa Warinta Tahun 2018

\begin{tabular}{|c|c|c|c|}
\hline No. & Jumlah Tanggungan (orang) & $\begin{array}{c}\text { Jumlah } \\
\text { (orang) }\end{array}$ & $\begin{array}{c}\text { Persen } \\
(\boldsymbol{\%})\end{array}$ \\
\hline 1 & $2-5$ & 20 & 62,5 \\
\hline 2 & $6-9$ & 12 & 37,5 \\
\hline & Total & 32 & 100 \\
\hline
\end{tabular}

Tabel 4 menunjukan bahwa petani responden yang memiliki jumlah tanggungan keluarga berkisar antara $2-5$ orang berjumlah 20 orang atau $62,5 \%$, petani responden yang memiliki jumlah tanggungan keluarga antara $6-9$ orang berjumlah 12 orang atau 37,5\%. Keadaan ini menggambarkan bahwa sebagian besar petani responden memiliki jumlah tanggungan keluarga yang dikategorikan dalam jumlah yang besar berdasarkan kondisi Desa Warinta. Jumlah tanggungan keluarga yang dimiliki petani responden diharapkan dapat memberikan kontribusi terutama dalam melakukan kegiatan usahatani sehingga dapat mengurangi biaya tenaga kerja dan dapat memperbesar pendapatan yang diterima oleh petani responden sebagai kepala keluarga.

4. Luas lahan garapan

Lahan garapan merupakan salah satu modal penting yang dimiliki oleh petani responden. Dengan lahan garapan petani responden dapat melakukan kegiatan usahatani jagung hibrida. Lahan tersebut dengan faktor- faktor produksi bibit, pupuk dan obat- obatan serta kemampuan petani responden dalam mengelola faktor- faktor produksi tersebut akan dapat menghasilkan jumlah produksi. Semakin luas lahan yang dimiliki dan digunakan untuk kegiatan usahatani maka semakin besar jumlah produksi yang dihasilkan dan semskin besar pula pendapatan yang diterima oleh petani .Luas lahan yang dimiliki oleh petani responden rata - rata 1,26 Hektar dengan kisaran 0,5 Hektar - 2,5 Hektar. Untuk lebih jelas keadaan luas lahan petani responden dapat dilihat pada Tabel 5.

Tabel 5. Keadaan Luas Lahan Pada Usahatani Jagung Hibrida Tahun 2017

\begin{tabular}{cccc}
\hline No & $\begin{array}{c}\text { Luas Lahan } \\
\text { (ha) }\end{array}$ & $\begin{array}{c}\text { Jumlah } \\
\text { (orang) }\end{array}$ & $\begin{array}{c}\text { Persen } \\
(\boldsymbol{\%})\end{array}$ \\
\hline 1 & $0,20-0,69$ & 26 & 81,25 \\
\hline 2 & $0,70-1,20$ & 6 & 18,75 \\
\hline & Total & 32 & 100,00 \\
\hline
\end{tabular}


Tabel 5 menunjukan petani responden yang memiliki luas lahan garapan berkisar antara $0,20-0,69$ hektar berjumlah 26 orang atau $81,25 \%$, petani responden yang memiliki luas lahan garapan berkisar antara $0,70-1,20$ Hektar berjumlah 6 orang atau 18,75\%. Keadaan ini menggambarkan bahwa sebagian besar petani responden memiliki luas lahan yang kecil sesuai kategori Desa Warinta. Diharapkan dengan luas lahan yang dimiliki tersebut, petani responden dapat memaksimalkan penggunaan lahan tersebut dengan memanfaatkan pengguanannya dan menerakan teknologi seperti pupuk, obat-obatan sehingga dengan lahan yang kecil akan tetapi dimanfaatkan secara maksimal maka akan mmeberikan hasil produksi yang maksimal.

\subsection{Pembahasan Hasil Penelitian}

\subsubsection{Analisis Efisiensi}

Analisis efisiensi usahatani jagung pada penelitian menggunakan fungsi regresi CobbDouglas. Input yang digunakan dalam model regresi ini adalah input jumlah tenaga kerja $\left(\mathrm{X}_{1}\right)$, pupuk $\left(\mathrm{X}_{2}\right)$, bibit $\left(\mathrm{X}_{3}\right)$ dan luas lahan $\left(\mathrm{X}_{4}\right)$. Model fungsi produksi Cobb-Douglas merupakan regresi non linear berganda. Agar dapat dianalisis harus ditransformasikan ke dalam bentuk persaman linear yaitu dengan logaritma natural. Model regresi fungsi produksi usahatani jagung di Desa Warinta dari hasil analisis statitik adalah sebagai berikut:

$\mathrm{Y}=3,473+0,059 \operatorname{Ln} \mathrm{X} 1+0,697 \operatorname{Ln} \mathrm{X} 2+0,225 \operatorname{Ln} \mathrm{X} 3+\mathrm{e}$

$\mathrm{Y}=$ produksi Jagung ipilan kering $(\mathrm{kg})$

$\mathrm{X}_{1}=$ jumlah tenaga kerja yang digunakan $(\mathrm{HOK})$

$\mathrm{X}_{2}=$ jumlah pupuk urea yang digunakan $(\mathrm{kg})$

$\mathrm{X}_{3}=$ jumlah bibit yang digunakan $(\mathrm{kg})$

Persamaan tersebut menunjukan hubungan antara tenaga kerja, pupuk dan bibit dengan hasil usahatani jagung. Berdasarkan analisis regresi diperoleh nilai sig sebesar 0,000. Nilai tersebut menunjukkan bahwa ada pengaruh secara bersama-sama dari faktor tenaga kerja, pupuk, dan bibit terhadap usahatani jagung. Besar nilai $\mathrm{R}^{2}$ adalah 0,991 , hal ini menunjukkan bahwa usahatani jagung dipengaruhi faktor tenaga kerja, pupuk, dan bibit yang digunakan dengan tingkat kepercayaan persamaan hampir $100 \%$ pasti sesuai dengan keadaan di lapangan, dengan kemungkinan kesalahan akibat faktor lain yang tidak diamati dalam penelitian ini sebesar $0,9 \%$.

Tabel 6. Hasil Analisis Uji t pengaruh tenaga kerja, pupuk, dan bibit terhadap usahatani jagung

\begin{tabular}{|c|c|c|c|c|c|c|}
\hline \multicolumn{2}{|c|}{ Model } & \multicolumn{2}{|c|}{$\begin{array}{c}\text { Unstandardized } \\
\text { Coefficients }\end{array}$} & \multirow{2}{*}{$\begin{array}{l}\begin{array}{l}\text { Standardized } \\
\text { Coefficients }\end{array} \\
\text { Beta }\end{array}$} & \multirow[t]{2}{*}{$\mathrm{t}$} & \multirow[t]{2}{*}{ Sig. } \\
\hline & & $\mathrm{B}$ & Std. Error & & & \\
\hline \multirow{4}{*}{1} & (Constant) & 3.473 & .430 & & 8.068 & .000 \\
\hline & $\begin{array}{l}\text { Tenaga Kerja } \\
\text { (X1) }\end{array}$ & .059 & .102 & .062 & .574 & .571 \\
\hline & Pupuk (X2) & .697 & .131 & .711 & 5.316 & .000 \\
\hline & Bibit (X3) & .225 & .080 & .229 & 2.824 & .009 \\
\hline
\end{tabular}


a. Dependent Variable: Produksi

$\mathrm{Y}=3,473+0,059 \operatorname{Ln} \mathrm{X} 1+0,697 \operatorname{Ln} \mathrm{X} 2+0,225 \operatorname{Ln} \mathrm{X} 3+\mathrm{e}$

Berdasarkan Tabel 6 diketahui nilai sig tenaga kerja sebesar 0,571 lebih besar dari 0,05, hal ini menunjukkan tenaga kerja tidak berpengaruh nyata terhadap usahatani jagung. Sedangkan nilai sig pupuk sebesar 0,000 lebih kecil dari nilai 0,05, hal ini menunjukkan jumlah pupuk berpengaruh nyata terhadap usahatani jagung. Nilai sig bibit sebesar 0,009 juga lebih kecil dari 0,05, hal ini menunjukkan jumlah bibit berpengaruh nyata terhadap produksi jagung. Dan berdasarkan nilai koefisien variabel bebas, yaitu tenaga kerja, pupuk, dan bibit terlihat nilai koefisien pupuk lebih besar variabel bebas lain, yaitu sebesar 0,697. Jadi pupuk secara parsial memberikan pengaruh lebih besar dibandingkan variabel bebas lainnya dan pengaruhnya bersifat sangat nyata dibandingkan yang lain, hal ini diketahui dari nilai sig variabel pupuk sebesar 0,000, lebih kecil daripada 0,01 .

Input yang digunakan dalam penelitian ini adalah input tenaga kerja, pupuk dan bibit. Efisiensi penggunaan faktor produksi ditentukan dengan cara membandingkan Nilai Produksi Marginal (NPM) faktor produksi dengan harga faktor produksi yang ditimbulkan. Dengan melihat harga input produksi maka diperoleh tingkat optimasi masing-masing input produksi. Data perhitungan nilai efisiensi dapat dilihat pada Tabel 7.

Tabel 7. Hasil analisis efisiensi tenaga kerja, pupuk, dan bibit di Desa Warinta Tahun 2018

\begin{tabular}{|c|l|r|r|r|r|r|r|}
\hline No & Faktor Produksi & \multicolumn{1}{l|}{ Xi } & \multicolumn{1}{l|}{ bi } & PFMxi & \multicolumn{1}{l}{ NPMxi } & \multicolumn{1}{l|}{ Pxi } & \multicolumn{1}{l|}{$\begin{array}{l}\text { NPMxi/ } \\
\text { Pxi }\end{array}$} \\
\hline 1 & Tenaga Kerja & 7.16 & 0.059 & 17.33048 & 60656.67 & $69,963.34$ & 0.8670 \\
\hline 2 & Pupuk & 181.44 & 0.697 & 8.079254 & $28,277.39$ & $2,537.86$ & 11.1422 \\
\hline 3 & Bibit & 6.97 & 0.225 & 67.89242 & 237623.46 & $60,000.00$ & 3.9604 \\
\hline \multicolumn{7}{|r}{} \\
\hline
\end{tabular}

Tabel 7 menunjukkan curahan tenaga kerja tidak efisien, hal ini dapat diketahui dari nilai NPMxi/Pxi sebesar 0,8670 lebih kecil dari nilai 1. Jadi perlu adanya pengurangan faktor curahan tenaga kerja agar efisien dapat tercapai. Untuk faktor produksi pupuk dan bibit dalam usahatani jagung belum mencapai efisiensi, hal ini dapat diketahui dari nilai NPMxi/Pxi lebih besar daripada 1 . Ini berarti jumlah faktor produksi pupuk dan bibit kurang banyak digunakan. Jadi perlu adanya penambahan faktor produksi pupuk dan bibit. Hal ini didasarkan dari pendapatan Soekartawi (2002) bahwa untuk mencapai efisiensi penggunaan input produksi diperoleh dengan membandingkan antara nilai produksi Marginal (NPM) faktor produksi dengan harga faktor produksi, dengan syarat jika nilai yang diperoleh NPM/PX $\geq 1$, maka penggunaan input produksi (tenaga kerja) belum efisien. Sebaliknya jika NPM/PX $<1$ berarti bahwa penggunaan faktor produksi $\mathrm{X}$ tidak efisien, sehingga perlu dilakukan pengurangan faktor produksi X agar dapat tercapai efisien.

\subsubsection{Analisis Pendapatan}

Struktur biaya produksi dapat dikategorikan dalam biaya tetap dan biaya variabel. Biaya tetap adalah biaya yang jumlahnya tidak berubah ketika kuantitas output berubah. Biaya variable adalah biaya yang besar kecilnya mempengaruhi kuantitas produksi.

a) Biaya Tetap (Fixed Cost)

Biaya tetap yang dikeluarkan antara lain ;

- Pajak Lahan

Pajak lahan yang dikeluarkan oleh petani jagung hibrida di Desa Warinta adalah sebesar 
Rp 40.000,-/ha dalam satu kali panen selama 3 bulan.

- Penyusutan peralatan yang digunakan

Dalam usahatani jagung hibrida peralatan yang digunakan adalah parang, karung, keranjang, tembilang, alat penyemprot, dan pisau. ini;

Adapun rincian biaya tetap yang dikeluarkan petani dapat dilihat pada tabel 8 berikut

Tabel 8. Rata-rata rekapitulasi biaya tetap petani jagung hibrida di Desa Warinta Kecamatan Pasarwajo tahun 2018

\begin{tabular}{llc}
\hline No & Jenis Biaya Tetap & Nilai $(\mathbf{R p )}$ \\
\hline 1 & Pajak lahan & $18.687,50$ \\
\hline 2 & Penyusutan & $39.290,49$ \\
\hline & Total & $57.977,99$ \\
\hline
\end{tabular}

Berdasarkan tabel 9 dijelaskan bahwa jumlah biaya tetap yang dikeluarkan petani jagung hibrida satu kali panen selama 3 bulan sebesar Rp 57.977,99.

b). Biaya tidak tetap (Variabel Cost)

Biaya tidak tetap yang

dikeluarkan petani jagung hibrida antara lain :

- Bibit

Bibit merupakan bahan baku utama yang akan menghasilkan produksi, oleh karena itu bibit unggul sangat diperlukan untuk mendapatkan produksi yang tinggi. Bibit yang digunakan petani adalah bibit jagung hibrida dengan harga $\mathrm{Rp} 60.000$,-/bungkus dan untuk 1 hektar dibutuhkan 15 bungkus. Biaya rata-rata yang dibutuhkan petani responden untuk bibit ini adalah $\mathrm{Rp} 390.000,00$.

- Pupuk

Jenis pupuk yang digunakan untuk usaha budidaya jagung hibrida ada dua macam yaitu pupuk kompos dan pupuk kimia. Adapun pupuk kimia yang digunakan yaitu ; urea, Fonska dan TSP. Total biaya rata-rata yang dibutuhkan petani responden untuk pupuk adalah sebesar Rp. 460.462,50

- Upah Tenaga Kerja

Upah tenaga kerja merupakan balas jasa yang diberikan kepada buruh tani atas kesediaannya membantu petani. Biaya rata-rata upah tenaga kerja adalah sebesar Rp 464.333,33.

Rincian pengeluaran biaya variabel (tidak tetap) yang dikeluarkan petani jagung hibrida di Desa Warinta Kecamatan Pasarwajo dapat dilihat pada tabel 10 dibawah ini.

Tabel 10. Rata-rata Rekapitulasi Biaya Variabel yang dikeluarkan petani jagung hibrida di Desa Warinta Kecamatan Pasarwajo tahun 2018

\begin{tabular}{clc}
\hline No & Jenis Biaya Variabel & Nilai $(\mathbf{R p )}$ \\
\hline 1 & Bibit & $418.125,00$ \\
\hline 2 & Pupuk & $460.462,50$ \\
\hline 3 & Tenaga Kerja & $500.937,50$ \\
\hline & Total & $1.379 .525,00$ \\
\hline
\end{tabular}


Berdasarkan tabel 10 diatas dapat dilihat bahwa penggunaan bibit rata-rata sebesar Rp 418.125,00 dan pupuk sebesar Rp 460.462,50, serta upah tenaga kerja yang dikeluarkan sebesar Rp 500.937,50.

Analisis pendapatan dapat diperoleh dengan terlebih dahulu mengetahui besarnya penerimaan dan biaya yang dikeluarkan dalam berusahatani jagung hibrida. Penerimaan merupakan keseluruhan uang yang diperoleh petani dari hasil penjualan jagung hibrida yang dikur dengan satuan rupiah. Rata-rata luas lahan yang digunakan petani 0.47 ha dengan produksi jagung yang dihasilkan sebanyak $2.103,16 \mathrm{~kg}$ dengan harga $\mathrm{Rp} 3.500,-/ \mathrm{kg}$. Adapun penerimaan rata-rata yang diperoleh petani dalam satu kali panen selama tiga bulan yaitu sebesar Rp 7.361.046,88. Analisis pendapatan dihitung berdasarkan jumlah uang yang diterima oleh petani dari hasil penjualan jagung hibrida dikurangi dengan biaya yang dikeluarkan. Adapun pendapatan rata-rata yang diterima petani jagung hibrida di Desa Warinta Kecamatan Pasarwajo Kabupaten Buton dapat dilihat pada tabel 11 berikut ini.

Tabel 11. Pendapatan rata-rata yang diperoleh Petani Jagung hibrida di Desa Warinta Kecamatan Pasarwajo tahun 2018

\begin{tabular}{lrrr}
\hline Uraian & Minimum & Maksimum & Rata-rata \\
\hline Luas Lahan & 0,20 & 1,20 & 0,47 \\
\hline Biaya Variabel & & & \\
\hline$-\quad$ Bibit & 180.000 & $960.000,00$ & $418.125,00$ \\
\hline$-\quad$ Pupuk & 189.500 & $1.055 .100,00$ & $460.462,50$ \\
\hline$-\quad$ Tenaga Kerja & 210.000 & $1.190 .000,00$ & $500.937,50$ \\
\hline$-\quad$ Total & 579.500 & $3.140 .000,00$ & $1.379 .525,00$ \\
\hline Biaya Tetap & \multicolumn{3}{c}{} \\
\hline$-\quad$ Pajak & 8.000 & 48.000 & $18.687,50$ \\
\hline$-\quad$ Penyusutan & $17.820,83$ & $82.683,33$ & $39.290,49$ \\
\hline$-\quad$ Total & $25.841,67$ & $122.683,33$ & $57.977,99$ \\
\hline Biaya Total & $605.341,67$ & $3.262 .683,33$ & $1.437 .502,99$ \\
\hline Produksi & 909,00 & $4.741,00$ & $2.103,16$ \\
\hline Harga & $3.500,00$ & $3.500,00$ & $3.500,00$ \\
\hline Penerimaan & $3.181 .500,00$ & $16.593 .500,00$ & $7.361 .046,88$ \\
\hline Pendapatan & $2.531 .445,83$ & $13.342 .900,00$ & $5.923 .543,88$ \\
\hline
\end{tabular}

Berdasarkan tabel 11 menunjukkan bahwa pendapatan rata-rata petani jagung hibrida satu kali panen selama 3 bulan di Desa Warinta Kecamatan Pasarwajo Kabupaten Buton sebesar Rp 5.923.543,88 dengan jumlah penerimaan rata-rata Rp 7.361.046,88 dan jumlah biaya yang dikeluarkan Rp 1.437.502,99.

\section{KESIMPULAN DAN SARAN}

Berdasarkan hasil penelitian dan pembahasan maka dapat diambil kesimpulan sebagai berikut :

1. Besar efisiensi harga faktor produksi tenaga kerja adalah sebesar 0,8670 . Perlu adanya pengurangan faktor curahan tenaga kerja agar efisiensi penggunaan tenaga kerja dapat tercapai.

2. Besar efisiensi harga faktor produksi pupuk adalah sebesar 11,1422. Perlu adanya penambahan faktor produksi pupuk agar efisiensi penggunaan pupuk dapat tercapai. 
3. Besarnya efisiensi harga faktor produksi bibit adalah sebesar 3,9604. Perlu adanya penambahan faktor produksi bibit agar efisiensi penggunaan bibit tercapat

4. Pendapatan rata-rata petani jagung hibrida satu kali panen di Desa Warinta Kecamatan Pasarwajo Kabupaten Buton adalah sebesar Rp 5.923.543,88 dengan jumlah penerimaan rata-rata sebesar Rp 7.361.046,88 dan jumlah biaya yang dikeluarkan sebesar Rp 1.437.502,99.

Berdasarkan kesimpulan maka saran yang dapat dikemukakan adalah sebagai berikut :

1. Petani jagung hibrida seharusnya lebih mengefisienkan biaya produksi serta memperbanyak pengetahuan tentang cara membudidayakan tanaman jagung hibrida sehingga produksi dapat meningkat yang akan mengakibatkan pendapatan juga turut meningkat.

2. Agar Instansi pemerintah berperan aktif dalam memberikan penyuluhan dan bimbingan kepada petani jagung hibrida, menyediakan bibit unggul dan pupuk serta menjaga kestabilan harga

\section{DAFTAR PUSTAKA}

Balai Penelitian Tanaman Serealia. 2002. Inovasi Teknologi Jagung, Menjawab Tantangan Ketahanan Pangan Nasional. Maros: Balai Penelitian Tanaman Sereal

Dewi Kusumawardani, 2003. Efisiensi Ekonomi Realtif dan Analisis Pendapatan Usahatani Tembakau Berdasarkan System Penguasaan Lahan sawah di Kabupaten Temanggung. Tesis MIESP Undip Semarang.

Kadariah, 1991, Analisis Pendapatan Nasional, Jakarta: Bina Aksara.

Kartasapoetra, A.G, 1988. Teknik Budidaya Tanaman Pangan di Daerah tropik. Bumi Aksara: Jakarta

Mosher, A. 1987. Menggerakan dan Membangun Pertanian. CV Yasaguna. Jakarta.

Nicholson, 1995. Mikroekonomi intermediate dan aplikasinya. Jakarta: Erlangga.

Partadiredja, Ace, 1990, Pengantar Ekonomika, Yogyakarta: BPFE.

Rukmana, R., 1994. Jagung: Budidaya dan Pascapanen. Kanisius, Yogyakarta.

Soekartawi, 2002. Analisis Usaha Tani. UI Press: Jakarta

Susantun. 2000. Fungsi keuntungan Cobb-Douglas dalam pendugaan efisiensi ekonomi relatif. Jurnal Ekonomi Pembangunan Vol. 5 No. 2

Tohir, A.K, 1983. Seuntai Pengetahuan Usaha Tani Indonesia. Rineka Cipta: Jakarta. 